\title{
ABSTRACTS
}

\section{What Went Wrong with Africa? On the Etiology of Sustaining Disarticulation of the African Nation-States}

\author{
By Isiaka Alani Badmus, Lagos
}

The central thrust of this study is a simple one: that the future of the 'nation-state' in Africa is uncertain due to the enormity of the threats it faces both from endogenous and exogenous forces. Furthermore, it contends that these forces, coupled with the globalization process are downsizing the 'nation-state' in Africa and thus states have been unable to manage policies in the best interests of the people. It is further posited that the determination and commitment of Africa's leaderships to improve the socio-economic conditions of the continent, democratization, and above all, equity and justice in the globalized world would save the situation.

\section{Unity in Diversity or Diversity in Unity: Indonesia's Process of Political Decentralisation and its Effects on Conflicts}

\section{By Hannah Neumeyer, London}

After the fall of the Suharto regime in 1998, Indonesia underwent an unprecedented process of political decentralisation. The main aim of this reform was the pacification of separatist movements that threatened the national integrity of one of the most diverse states in the world.

The essay explores the process of decentralisation from the drafting to the implementation stage and asks whether the aim of the reform has been achieved.

Shortcomings of the rapid drafting process are highlighted and possible political, practical and ideological explanations for those flaws are given. An analysis of the centrepiece of the reform legislation shows that it needs further clarification. This in itself is highlighted as a problem because of the still relatively unstable political conditions in Indonesia.

Finally, the special autonomy legislation for Papua serves as a case study to answer the initial question. The background of the Papuan independence movement and the development of special autonomy are described. It is suggested that the commitment of the central government to accommodating reasonable demands of the Papuan population has been and remains far from stable. 
The essay concludes that the reform has not only been unsuccessful in its aim to pacify separatist movements, but has also created a new form of conflict in Indonesia.

\title{
The avised revision of the "Peace-clause" in Japanese Constitutional Law
}

\author{
By Dirk Hasler, Regensburg
}

Japan acquired an "obligation to internationalism" through its constitution, which was developed immediately following World War II. At the heart of the constitutional norms containing this obligation is the essential element Art. 9, whose interpretation dominates the political and scientific disputes over Japanese foreign and security policy to this day. This is all the more remarkable, because when using a consequent juridical interpretation methodology, the popular yet contradictory interpretations cannot be fully traced back to the actual text of the norm.

Prevalent among constitutional scholars, the strictly pacifistic interpretation renounces any form of self-defense of the Japanese state, as well as the legality of a national military organisation, but proves to be highly selective under historical perspective and neglects systematic connections to public international law. The contrary position, which can be called "legality-interpretation", differentiates between a legal individual self-defense and a forbidden collective self-defense - a separation that is in no way derived from the original text of the norm.

Art. 9 effectively represents a national adaptation of Art. 2 IV and 51 CUN, but the theoretical confusion between self-preservation, individual and collective self-defense allowed enough room for those kind of interpretation that proved useful for the day-to-day struggle in foreign policy decision-making.

Despite innumerable proposals to adjust Art. 9 to "reality", though often under use of a narrow and ideologically odoured definition of realism in international relations theory, current discussions offer the possibility for the Japanese government to show its real commitment to pacifism.

\section{The New Legal Education in the P.R. China}

\section{By Björn Ahl, Nanjing}

This article introduces the new Chinese national uniform judicial examination and explores the role of the examination in promoting the development of rule of law in People's Republic of China. Based on an analysis of the examination questionnaires, the article 
concludes that the judicial examination is mostly aimed at the technical requirements of law. The questions indicate a turning away from rule by law and reflect a non-liberal conception of rule of law, although some points are so broadly stated that they can even be reconciled with a liberal rule-of-law model. Therefore, the legal knowledge and technical legal skills that are subjects of the examination indicate an increased professionalism and bear the potential of developing an independent legal profession similar to that of liberal rule-of-law systems. 